\title{
MORPHOLOGICAL ASSESSMENTS OF ROOT APEX OF PERMANENT MANDIBULAR FIRST AND SECOND PREMOLARS IN A TURKISH POP. ULATION
}

\author{
FIDAN BABAYEVA $^{1}$, EKIM ONUR ORHAN ${ }^{\bowtie, 1,2,3}$, OZGUR IRMAK $^{4}$ \\ ${ }^{1}$ Department of Endodontics Faculty of Dentistry, Eskişehir Osmangazi University, 26040 Eskişehir, Turkey; \\ ${ }^{2}$ Translational Medicine Research and Clinical Center, Eskisehir Osmangazi University, 26040 Eskisehir, \\ Turkey; ${ }^{3}$ Computer-Aided Diagnosis and Treatment Application and Research Center in Healthcare, Eskisehir \\ Osmangazi University, 26040 Eskisehir, Turkey; ${ }^{4}$ Department of Restorative Dentistry, Faculty of Dentistry, \\ Near East University, Nicosia / TRNC Mersin 10, Turkey. \\ e-mail: ekimorhan@ogu.edu.tr,dt.fidanbabayeva@gmail.com,zgrrmk@gmail.com \\ (Received May 27, 2021; revised October 6, 2021; accepted November 9, 2021)
}

\begin{abstract}
There is no apical morphological data being available for mandibular first or second premolars in the Turkish population. The aims of the study were (I) to assess apical morphological data of mandibular first and second premolars in a Turkish population at a young-adult age range (II) to analyze potential correlations between the size and position of the apical foramina (AF). Extracted sound teeth were collected from an adult volunteer population as willing to donate. Morphological data were obtained from specimens using a stereomicroscope. The number, size, shape, and position of AF and frequency of accessory foramina were quantified. Mann-Whitney U and Spearman's rank correlation tests were performed $(\alpha=0.05)$. A total of 237 teeth were investigated. The majority of the specimens had one major AF. The frequency of major AF was between 1-3 for both groups. The median AF size in mandibular first and second premolars were $55,180 \mu \mathrm{m}^{2}$ and $67,483 \mu \mathrm{m}^{2}$, respectively. The majority of foramina shape was irregular for the mandibular first premolars whereas, was oval for the second premolars. The median location of AF with respect to the anatomic apex was $664 \mu \mathrm{m}$ in mandibular first premolars and $677 \mu \mathrm{m}$ in mandibular second premolars. The size and location of AF mostly overlap between the mandibular first and second premolars. The shape of the AF might be the only relevant variation concerning the apical morphology between the mandibular first and second premolars in young adults. The interaction between the size and location of AF in mandibular premolars of young adults seems not significant.
\end{abstract}

Keywords: apical foramina, apical morphology, dentistry, mandibular premolars, medical image analysis.

\section{INTRODUCTION}

The success of root canal treatment requires accurate projection of root canal anatomy and apical morphology thus that the root canal system can not only be negotiated but also inflamed pulp tissue can be effectively removed (Vertucci, 2005). In addition, having information about apical morphology allows the appropriate determination of working dimensions during the root canal treatment practice (European Society of Endodontology, 2006). Basically, accurately determining the initial working dimensions according to morphological limits is a key factor in achieving biomechanical shaping and hermetic sealing goals (Wu et al., 2000). In clinical practice, the exact localization of the invisible apical foramina is sought together with X-ray imaging techniques and electronic apex locator instrument signals (European Society of Endodontology, 2006). However, the exact location of the invisible apical foramina is still controversial. There are two hypotheses regarding the final boundary of root canal treatment: (I) the largest space of the apical opening of the main canal (Stein et al., 1992), (II) the narrowest space of the apical opening of the main canal (Ricucci, 1998).

Morphologically, the location of the main apical foramina does not always intersect at the anatomic apex. In the other words, it can locate away from the anatomic apex due to racial, developmental, or pathological reasons (Dummer et al., 1984; Blasković-Subat Marroquín et al., 2004). Especially, the apical morphology might vary depending on the population characteristics (Ahmed et al., 2017). Accordingly, previous studies conducted on apical morphology have reported a wide range of variations between populations, within the population, and individually (Gulabivala et al., 2001; Sert and 
Bayirli, 2004; Peiris, 2008; Song et al., 2010; Zhang et al., 2014).

Specifically, the root canal anatomy of permanent mandibular premolars is highly variable (Zillich and Dowson, 1973). Previous studies summarized in Table 1 have reported the root canal anatomy of mandibular premolars and indicated that the apical anatomy may be affected by racial factors (Vertucci, 1978; Trope et al., 1986; Walker, 1988; Calişkan et al., 1995; Sert and Bayirli, 2004; Kim et al., 2005; Lu et al., 2006; Awawdeh and Al-Qudah, 2008; Awawdeh et al., 2019).
Moreover, variations are seen in mandibular premolars can affect the clinical success (Orhan et al., 2017).

The location and size of apical foramina might be affected by increasing age due to continuous cementum production (Zillich and Dowson, 1973). However, a previous study has reported that there is no significant interaction between the location or size of apical foramina and within the age range of 18-50 in mandibular first premolars (Awawdeh et al., 2019). To the best of the authors' knowledge, there is no apical morphological data being available for mandibular first or second premolars in the Turkish population at a specific age range.

Table 1. Studies of apical root morphology in mandibular premolars.

\begin{tabular}{|c|c|c|c|c|c|c|c|c|}
\hline \multirow[b]{2}{*}{ Reference } & \multicolumn{3}{|c|}{ Sample size } & \multicolumn{5}{|c|}{ Methodology } \\
\hline & $\begin{array}{c}\text { Total sample } \\
\text { size (data ac- } \\
\text { quisition) }\end{array}$ & $\begin{array}{l}\text { Mandibu- } \\
\text { lar first } \\
\text { premolar }\end{array}$ & $\begin{array}{l}\text { Mandibu- } \\
\text { lar second } \\
\text { premolar }\end{array}$ & $\begin{array}{l}\text { Investiga- } \\
\text { tion }\end{array}$ & AF size & $\begin{array}{c}\text { AA to } A F \text { loca- } \\
\text { tion }\end{array}$ & $\begin{array}{c}\text { Matched AF } \\
\text { shapes }\end{array}$ & $\begin{array}{c}\text { Accessory AF infor- } \\
\text { mation }\end{array}$ \\
\hline Green (1960) & $\begin{array}{l}400 \text { teeth } \\
\left({ }^{*} N Y, \text { USA) }\right.\end{array}$ & 50 teeth & 50 teeth & $\begin{array}{l}\text { Stereomi- } \\
\text { croscopy }\end{array}$ & $\begin{array}{l}\text { minima and } \\
\text { maxima } \\
\text { lengths of } \\
\text { the } A F(\mathrm{~mm})\end{array}$ & $\begin{array}{l}\text { Length deter- } \\
\text { mination (mm) }\end{array}$ & $\begin{array}{l}\text { Round, oval, } \\
\text { serrated, } \\
\text { asymmet- } \\
\text { rical, funnel }\end{array}$ & $\begin{array}{l}\text { Frequency infor- } \\
\text { mation. Average di- } \\
\text { ameter and average } \\
\text { distance of acces- } \\
\text { sory foramina }(\mathrm{mm})\end{array}$ \\
\hline $\begin{array}{l}\text { Zillich and } \\
\text { Dowson } \\
(1973)\end{array}$ & $\begin{array}{l}2331 \text { teeth } \\
\left({ }^{*} \mathrm{MI}, \mathrm{USA}\right)\end{array}$ & 1393 teeth & 938 teeth & $\begin{array}{l}\text { Radiog- } \\
\text { raphy }\end{array}$ & N/A & N/A & N/A & N/A \\
\hline $\begin{array}{l}\text { Vertucci } \\
(1978)\end{array}$ & $\begin{array}{l}800 \text { teeth } \\
\left({ }^{*} \mathrm{FL}, \mathrm{USA}\right)\end{array}$ & 400 teeth & 400 teeth & Clearing & N/A & N/A & N/A & N/A \\
\hline $\begin{array}{l}\text { Dummer et } \\
\text { al., (1984) }\end{array}$ & $\begin{array}{c}270 \text { teeth } \\
\left({ }^{*} \text { Cardiff, }\right. \\
\text { UK) }\end{array}$ & \multicolumn{2}{|c|}{53 teeth } & $\begin{array}{l}\text { Stereomi- } \\
\text { croscopy }\end{array}$ & N/A & $\begin{array}{l}\text { Length deter- } \\
\text { mination (mm) }\end{array}$ & N/A & N/A \\
\hline $\begin{array}{l}\text { Walker } \\
\text { (1988) }\end{array}$ & $\begin{array}{l}100 \text { teeth } \\
\text { (Southern } \\
\text { China) }\end{array}$ & 100 teeth & N/A & $\begin{array}{l}\text { Radiog- } \\
\text { raphy }\end{array}$ & N/A & N/A & N/A & N/A \\
\hline $\begin{array}{l}\text { Caliskan et } \\
\text { al., (1995) }\end{array}$ & $\begin{array}{l}1400 \text { teeth } \\
\text { (İzmir, Tur- } \\
\text { key) }\end{array}$ & 100 teeth & 100 teeth & Clearing & N/A & $\begin{array}{l}\text { Frequency; } \\
\text { central or lat- } \\
\text { eral }\end{array}$ & N/A & N/A \\
\hline $\begin{array}{l}\text { Sert and } \\
\text { Bayirli (2004) }\end{array}$ & $\begin{array}{l}2800 \text { teeth } \\
\text { (İstanbul, } \\
\text { Turkey) }\end{array}$ & $\begin{array}{l}200 \text { teeth } \\
\text { identified } \\
\text { by gender }\end{array}$ & $\begin{array}{l}200 \text { teeth } \\
\text { identified } \\
\text { by gender }\end{array}$ & Clearing & N/A & $\begin{array}{l}\text { Frequency; } \\
\text { central or lat- } \\
\text { eral }\end{array}$ & N/A & $\begin{array}{l}\text { Frequency infor- } \\
\text { mation }\end{array}$ \\
\hline $\begin{array}{l}\text { Awawdeh } \\
\text { and Al-Qudah } \\
\text { (2008) }\end{array}$ & $\begin{array}{l}900 \text { teeth } \\
\text { (North Jor- } \\
\text { dan) }\end{array}$ & 500 teeth & 400 teeth & Clearing & N/A & $\begin{array}{l}\text { Frequency; } \\
\text { central or lat- } \\
\text { eral }\end{array}$ & N/A & N/A \\
\hline $\begin{array}{l}\text { Hassanien et } \\
\text { al., (2008) }\end{array}$ & $\begin{array}{l}60 \text { teeth } \\
\left({ }^{*} \text { Cairo, }\right. \\
\text { Egypt })\end{array}$ & 30 teeth & 30 teeth & $\begin{array}{l}\text { Stereomi- } \\
\text { croscopy }\end{array}$ & N/A & $\begin{array}{l}\text { Length deter- } \\
\text { mination of RA } \\
\text { to CDJ }(\mathrm{mm})\end{array}$ & N/A & N/A \\
\hline $\begin{array}{l}\text { Arora and } \\
\text { Tewari (2009) }\end{array}$ & $\begin{array}{l}800 \text { teeth } \\
\text { (Hayrana, } \\
\text { North India) }\end{array}$ & $\begin{array}{l}\text { Yes; non- } \\
\text { disclosed } \\
\text { sample } \\
\text { size per } \\
\text { group }\end{array}$ & $\begin{array}{l}\text { Yes; non- } \\
\text { disclosed } \\
\text { sample } \\
\text { size per } \\
\text { group }\end{array}$ & $\begin{array}{l}\text { Stereomi- } \\
\text { croscopy }\end{array}$ & $\begin{array}{l}\text { minima and } \\
\text { maxima } \\
\text { lengths of } \\
\text { the } A F(\mathrm{~mm})\end{array}$ & $\begin{array}{l}\text { Length deter- } \\
\text { mination (mm) }\end{array}$ & $\begin{array}{l}\text { Round, oval, } \\
\text { irregular }\end{array}$ & $\begin{array}{l}\text { Frequency infor- } \\
\text { mation and max. } \\
\text { and min. diameter } \\
\text { of accessory foram- } \\
\text { ina (mm) }\end{array}$ \\
\hline $\begin{array}{l}\text { Awawdeh et } \\
\text { al., (2019) }\end{array}$ & $\begin{array}{c}101 \text { teeth } \\
\text { (*Irbid, Jor- } \\
\text { dan) }\end{array}$ & $\begin{array}{l}101 \text { teeth } \\
\text { Identified } \\
\text { by age and } \\
\text { gender }\end{array}$ & N/A & $\begin{array}{l}\text { Stereomi- } \\
\text { croscopy }\end{array}$ & $\begin{array}{l}\text { minima and } \\
\text { maxima } \\
\text { lengths of } \\
\text { the AF }(\mathrm{mm}) \\
\text { AF area }\end{array}$ & $\begin{array}{l}\text { Length deter- } \\
\text { mination (mm) }\end{array}$ & $\begin{array}{l}\text { Round, oval, } \\
\text { irregular }\end{array}$ & $\begin{array}{l}\text { Frequency infor- } \\
\text { mation }\end{array}$ \\
\hline Present study & $\begin{array}{c}237 \text { teeth } \\
\text { (Eskişehir, } \\
\text { Turkey) }\end{array}$ & $\begin{array}{l}124 \text { teeth } \\
\text { Young } \\
\text { adults }\end{array}$ & $\begin{array}{l}113 \text { teeth } \\
\text { Young } \\
\text { adults }\end{array}$ & $\begin{array}{l}\text { Stereomi- } \\
\text { croscopy }\end{array}$ & $\begin{array}{l}\left(\mu \mathrm{m}^{2}\right)+\text { min- } \\
\text { ima and } \\
\text { maxima } \\
\text { lengths of } \\
\text { the } A F(\mu \mathrm{m})\end{array}$ & $\begin{array}{l}\text { Length deter- } \\
\text { mination }(\mu \mathrm{m})\end{array}$ & $\begin{array}{l}\text { Round, oval, } \\
\text { triangle, rib- } \\
\text { bon, C-type, } \\
\text { irregular }\end{array}$ & $\begin{array}{l}\text { Frequency infor- } \\
\text { mation }\end{array}$ \\
\hline
\end{tabular}


With this motivation, the present study was purposed to examine, in particular, apical morphology in young adults using a stereomicroscopic technique. More specifically, the aim of this study was (i) to assess apical morphological data of mandibular first and second premolars in a Turkish population at a young-adult age range (ii) to analyze potential correlations between the size and position of the foramina. For this purpose, the apical morphology of mandibular first and second premolars belongs to young adults was investigated ex vivo.

\section{MATERIAL AND METHODS}

\section{ETHICAL STATEMENT}

The study protocol was performed in accordance with relevant guidelines and regulations. The protocol was approved by the Human Subjects Office, Office of Non-Invasive Research Compliance - Eskisehir Osmangazi University (Study no. 218, issue date: 11.12.2018 with reference \#: 25403353-0.50.99-E.134832).

\section{SPECIMEN PREPARATION AND PRO- CESSING}

A total of 278 extracted teeth with varied reasons were collected from an adult volunteer population as willing to donate. The mean age of volunteers was $25.4 \pm 4.6$ (demographic data were not shown). Informed consent was obtained from all teeth donors. According to the donor records, mandibular first premolars were mostly obtained by extraction for orthodontic purposes whereas, second premolars were mostly obtained by surgical extraction of impacted teeth.

Tissue remnants on the root surface were gently removed with a scaler hand instrument. Teeth specimens were divided into two groups as mandibular first and second premolars. Until the microscopic examination, the teeth specimens were kept in freshly prepared $0.1 \%$ thymol from the pure grade powder $(\geq 99 \%$ Thymol Lot\# 2019448; Carl Roth, Karlsruhe, Germany). Thymol suspension was renewed each day.

To provide the color-contrasting among the hard and soft tissues, specimens were dyed with methylene blue, were washed and dried. Then the anatomic apex was pointed out as a reference by marking in red ink and a micro-brush. The crowns were embedded into silicon impression material-filled molds.

\section{DATA COLLECTION AND IMAGE ANALYSIS}

A stereomicroscope (Stemi 508; Carl Zeiss Microscopy GmbH, Göttingen, Germany), a computer-assisted binocular with 50x magnification, and a photo attachment (Axiocam 105 color; Carl Zeiss Microscopy
$\mathrm{GmbH}$, Germany) were used for the image data collection.

Image data were displayed at 2,560 $\times 1,600$ resolution (Intel Iris Plus Graphics 645 graphic card) using the image analysis module of the Zen2Lite software (Carl Zeiss Microscopy GmbH, Jena, Germany). The calibration of measurement was performed according to a $0.1 \mathrm{~mm}$ reference microscale of software. For each image datum, the largest space of the apical opening of the main canal was defined as apical foramina (AF). If any AF area was less than $7800 \mu \mathrm{m}^{2}$ or maximum width $<100 \mu \mathrm{m}$, AF was defined as accessory foramina (Awawdeh et al., 2019).

Each specimen was oriented inside its mold until the $\mathrm{AF}$ was centered and parallel to the objective lens. When orientation was precisely conducted, the image was focused and captured. If a root has more than one AF, individual image data were obtained by each AF by focusing parallel to the objective lens. First, the regions of interest (ROI) or the outer shape of each AF was defined via the selection tool of the software. Subsequently, each ROI was measured using the area measurement tool of the software. Measured AF data represented the size, shape, and frequency of the major apical foramina. The indicated anatomic apex was pointed out as a reference in the software. Then, the distance between the reference and the ROI was measured (A-F) via the distance measurement tool. Measured A-F data represented the location of the major apical foramina. When the AF did not intersect with the reference, the shortest distance from the reference point to the tangent line of AF was drawn, which was used to determine the A-F distance. If a specimen had more than one AF, the largest AF was held to consider in A-F measurements. Each size was expressed as $\mu \mathrm{m}^{2}$ whereas each distance was expressed as $\mu \mathrm{m}$. Also, the widest and narrowest diameters of each ROI were measured using the linear measurement mode of the software and defined as the wide and narrow diameters of $\mathrm{AF}(\mu \mathrm{m})$, respectively. Each analyzed image was saved in the CZI format (Carl Zeiss Microscopy GmbH, Jena, Germany). This file format allows the storage of

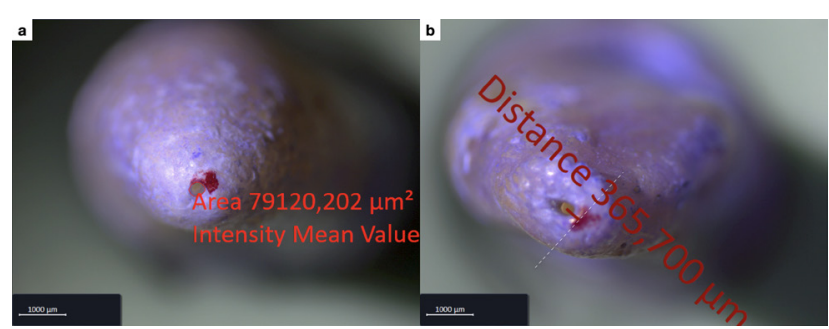

Fig. 1. A representative screenshot of image data a; region of interest determination for measuring the size of apical foramina, $b$; length measurement tool (The white dashed line corresponds to anatomic apex). 
specific annotations and saved measured values, Fig. 1. The dataset can be found in Supplementary online material entitled "Supplementary file S1". Also, access to original CZI material is possible upon request to the corresponding author or F. B.

\section{STATISTICAL ANALYSIS}

Statistical analysis was performed using software (GraphPad Prism 9; GraphPad Software; San Diego, CA) $(\alpha=0.05)$. D'Agostino \& Pearson omnibus normality test revealed that data were not normally distributed $(p<0.001)$. Therefore, the Mann-Whitney U test sought to determine the difference between groups. Spearman's rank correlation test sought to assess the correlation between the size and location of AF within the groups.

\section{RESULTS}

Root fractures, root resorptions, immature teeth, or root canal-filled teeth detected high magnification were excluded from the study $(n=41)$. Consequently, a total of 237 teeth were included in the study. Among the teeth, $52 \%(\mathrm{n}=124)$ were first premolars and $48 \%$ $(\mathrm{n}=113)$ were second premolars. The power of the sample size was computed as $>99 \%(\alpha=0.05, \beta / \alpha=1.097)$ using software ( $G^{*}$ Power v3.1; Düsseldorf, Germany).

Frequency of major and accessory foramina in mandibular premolars are summarized in Table 2. The majority of the specimens had one AF. The frequency of AF of specimens was between 1-3 for both groups, Fig. 2. The frequency of accessory foramina was between $0-2$ for both groups.

The median areal values and quartiles (1-3) of specimens' size of foramen A-F distance are summarized in Table 3. The median (Q1-Q3) AF size in mandibular

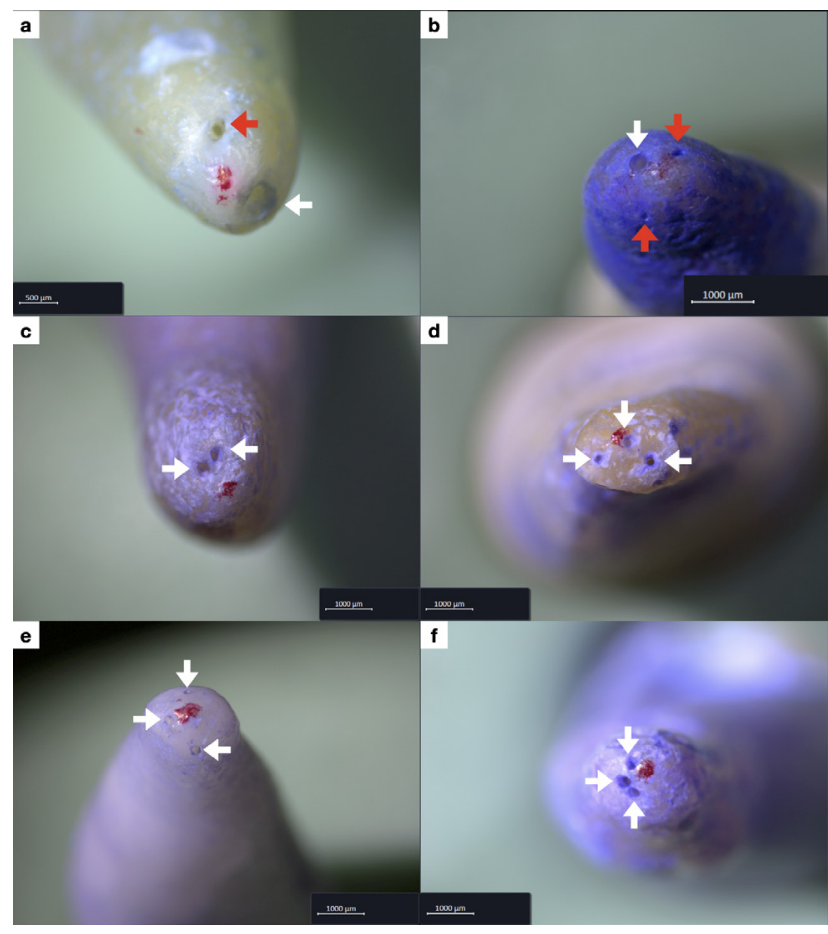

Fig. 2. Representative image data of different frequencies of apical foramina. a; one major apical foramina with one accessory apical foramina, $b$; one major apical foramina with two accessory foramina, $c$; two major apical foramina, $d$, e and $f$; three major apical foramina.

first and second premolars were $55,180 \mu \mathrm{m}^{2}(39,119-$ $85,639)$ and $67,483 \mu \mathrm{m}^{2}(43,757-98,410)$, respectively $(\mathrm{p}=0.101)$. The median linear values of foramen and quartiles (1-3) are summarized in Table 4. The maximum widths of AF in mandibular first and second premolars were $272 \mu \mathrm{m}(51.8-786)$ and $298 \mu \mathrm{m}(110-863)$, respectively $(\mathrm{p}=0.071)$. Whereas, the minimum width in mandibular first and second premolars were $194 \mu \mathrm{m}$ (40.1-441) and $213 \mu \mathrm{m}$ (74.8-515), respectively $(\mathrm{p}=0.096)$.

Table 2. Frequency of major and accessory foramina in mandibular premolars

\begin{tabular}{|c|c|c|c|c|}
\hline \multirow[b]{2}{*}{$\begin{array}{c}\text { Number of major/acces- } \\
\text { sory foramina }\end{array}$} & \multicolumn{2}{|c|}{ Mandibular first premolars } & \multicolumn{2}{|c|}{ Mandibular second premolars } \\
\hline & $\begin{array}{l}\text { Number of teeth } \\
\text { (percentage) with } \\
\text { major foramina }\end{array}$ & $\begin{array}{c}\text { Number of teeth } \\
\text { (percentage) with ac- } \\
\text { cessory foramina }\end{array}$ & $\begin{array}{c}\text { Number of major/ac- } \\
\text { cessory foramina }\end{array}$ & $\begin{array}{c}\text { Number of teeth } \\
\text { (percentage) with } \\
\text { major foramina }\end{array}$ \\
\hline 0 & $0(0.0)$ & $108(87.8)$ & $0(0.0)$ & $96(84.2)$ \\
\hline 1 & $110(89.4)$ & $13(10.5)$ & $98(85.9)$ & $15(13.1)$ \\
\hline 2 & $11(8.9)$ & $2(1.6)$ & $12(10.5)$ & $3(2.6)$ \\
\hline 3 & $2(1.6)$ & $0(0.0)$ & $4(3.5)$ & $0(0.0)$ \\
\hline Total & 123 & $00.0)$ & 11 & .0) \\
\hline
\end{tabular}


Table 3. Frequency of major and accessory foramina in mandibular premolars

\begin{tabular}{|c|c|c|c|c|c|c|c|}
\hline \multirow[t]{2}{*}{ Groups } & \multirow[t]{2}{*}{$\mathrm{n}$} & \multicolumn{2}{|c|}{ Size of foramen $\left(\mu \mathrm{m}^{2}\right)$} & \multicolumn{2}{|c|}{ A-F distance $(\mu \mathrm{m})$} & \multirow[b]{2}{*}{ rho } & \multirow[b]{2}{*}{$\begin{array}{c}\mathrm{P} \\
\text { value }\end{array}$} \\
\hline & & Median (min-max) & Q1-Q3 & $\begin{array}{l}\text { Median (min- } \\
\text { max) }\end{array}$ & Q1-Q3 & & \\
\hline $\begin{array}{l}\text { Mandibular } \\
\text { first premo- } \\
\text { lar }\end{array}$ & $\begin{array}{c}124 \\
(52 \%)\end{array}$ & $\begin{array}{c}55180 \\
(8273-891992)\end{array}$ & $\begin{array}{l}39119- \\
85639\end{array}$ & $\begin{array}{c}664.00 \\
(0.00-2082.00)\end{array}$ & $512.00-907.50$ & 0.035 & $0.692^{\Psi}$ \\
\hline $\begin{array}{l}\text { Mandibular } \\
\text { second pre- } \\
\text { molar }\end{array}$ & $\begin{array}{c}113 \\
(48 \%)\end{array}$ & $\begin{array}{c}67483 \\
(9141-353367)\end{array}$ & $\begin{array}{l}43757- \\
98410\end{array}$ & $\begin{array}{c}677.00 \\
(0.00-6489.00)\end{array}$ & $515.50-1053.00$ & -0.042 & $0.651^{\Psi}$ \\
\hline $\mathrm{P}$ value & & $0.101 *$ & & 0.37 & & & \\
\hline Total & 237 & $\begin{array}{l}\text { Q1 shows the } 25 \% \mathrm{o} \\
\text { from anatomic apex t } \\
\text { derived from *Mann- }\end{array}$ & $\begin{array}{l}\text { ercentile } \\
\text { oramen, } \\
\text { hitney U }\end{array}$ & $\begin{array}{l}\text { ereas, Q3 shows th } \\
\text {; Spearman's rank } \\
\text { s, 'Spearman's rar }\end{array}$ & $\begin{array}{l}75 \% \text { of percenti } \\
\text { orrelation coeffic } \\
\text { x correlation tests }\end{array}$ & $\begin{array}{l}\text { A-F; di } \\
\text { nt. P val } \\
=0.05)\end{array}$ & $\begin{array}{l}\text { tance } \\
\text { es are }\end{array}$ \\
\hline
\end{tabular}

Table 4. The median linear values and quartiles (1-3) of specimens

\begin{tabular}{|c|c|c|c|c|c|}
\hline \multirow{2}{*}{ Groups } & \multirow{2}{*}{$\mathrm{n}$} & \multicolumn{2}{|c|}{ Max. width of AF $(\mu \mathrm{m})$} & \multicolumn{2}{|c|}{ Min. width of AF $(\mu \mathrm{m})$} \\
\hline & & $\begin{array}{c}\text { Median } \\
(\min -\max )\end{array}$ & Q1-Q3 & $\begin{array}{c}\text { Median } \\
(\text { min-max })\end{array}$ & Q1-Q3 \\
\hline Mandibular first premolar & $\begin{array}{c}124 \\
(52 \%)\end{array}$ & $272(51.8-786)$ & $220-346$ & 194 & $40.1-441$ \\
\hline $\begin{array}{l}\text { Mandibular second pre- } \\
\text { molar }\end{array}$ & $\begin{array}{c}113 \\
(48 \%) \\
\end{array}$ & $298(110-863)$ & $244-381$ & 213 & $74.8-515$ \\
\hline Total & 237 & $\begin{array}{l}\qquad \mathrm{P}= \\
\text { Q1 shows the } 25 \\
\mathrm{P} \text { shows the } \mathrm{P} \text { Va }\end{array}$ & $\begin{array}{l}\text { f percentile } \\
\text { derived frc }\end{array}$ & $\begin{array}{l}\text { s, Q3 shows } \\
\text { n-Whitney U }\end{array}$ & $\begin{array}{l}\text { of percentile, } \\
=0.05)\end{array}$ \\
\hline
\end{tabular}

Table 5. Frequency of major foramina shapes in mandibular premolar

\begin{tabular}{|c|c|c|c|c|c|c|c|}
\hline Groups & $\begin{array}{c}\text { Number of } \\
\text { teeth } \\
\text { (percentage) }\end{array}$ & $\begin{array}{c}\text { Number of } \\
\text { teeth } \\
\text { (percentage) } \\
\text { with round } \\
\text { major } \\
\text { foramina }\end{array}$ & $\begin{array}{l}\text { Number of } \\
\text { teeth } \\
\text { (percentage) } \\
\text { with oval } \\
\text { major } \\
\text { foramina }\end{array}$ & $\begin{array}{c}\text { Number of } \\
\text { teeth } \\
\text { (percentage) } \\
\text { with trian- } \\
\text { gle major } \\
\text { foramina }\end{array}$ & $\begin{array}{c}\text { Number of } \\
\text { teeth } \\
\text { (percentage) } \\
\text { with ribbon- } \\
\text { shape major } \\
\text { foramina }\end{array}$ & $\begin{array}{c}\text { Number of } \\
\text { teeth } \\
\text { (percentage) } \\
\text { with C-type } \\
\text { major } \\
\text { foramina }\end{array}$ & $\begin{array}{c}\text { Number of } \\
\text { teeth } \\
\text { (percentage) } \\
\text { with } \\
\text { irregular- } \\
\text { shaped major } \\
\text { foramina }\end{array}$ \\
\hline $\begin{array}{l}\text { Mandibular } \\
\text { first } \\
\text { premolar }\end{array}$ & $124(52.3)$ & $30(24.3)$ & $38(30.8)$ & $4(3.2)$ & $0(0.0)$ & $0(0.0)$ & $48(38.2)$ \\
\hline $\begin{array}{l}\text { Mandibular } \\
\text { second } \\
\text { premolar }\end{array}$ & $113(47.7)$ & $37(32.7)$ & $40(35.3)$ & $3(2.6)$ & $2(1.6)$ & $2(1.6)$ & $33(29.2)$ \\
\hline Total & $237(100.0)$ & $67(28.2)$ & 78 (32.9) & $7(2.9)$ & $2(0.8)$ & $2(0.8)$ & $81(34.2)$ \\
\hline
\end{tabular}


The boxplots of major AF size of specimens are given in Fig. 3. The shapes of AF are summarized in Table 5. The majority of AF shape of specimens were irregular $(38.2 \%)$ for the mandibular first premolars whereas, was oval (35.3\%) for the mandibular second premolars Figs. 4 and 5.

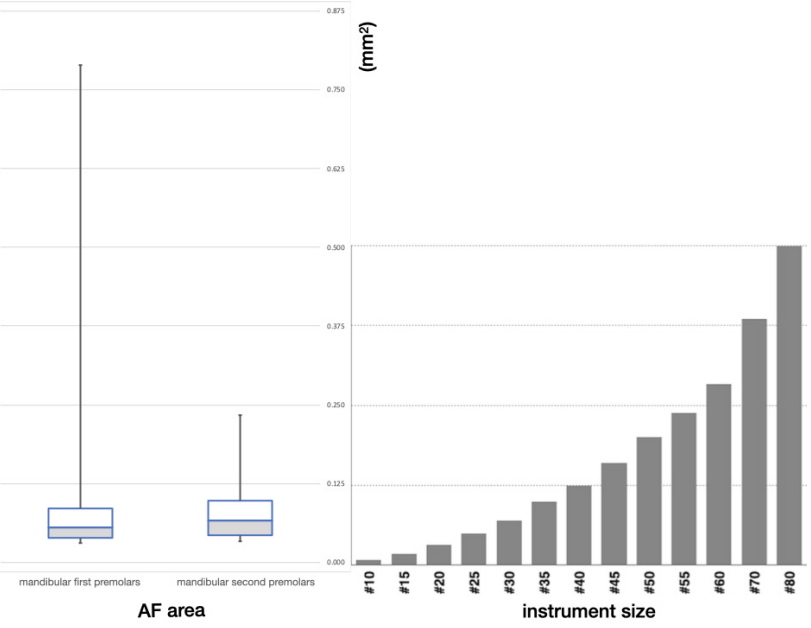

Fig. 3. Apical foramen size boxplot versus instrument size bar chart.

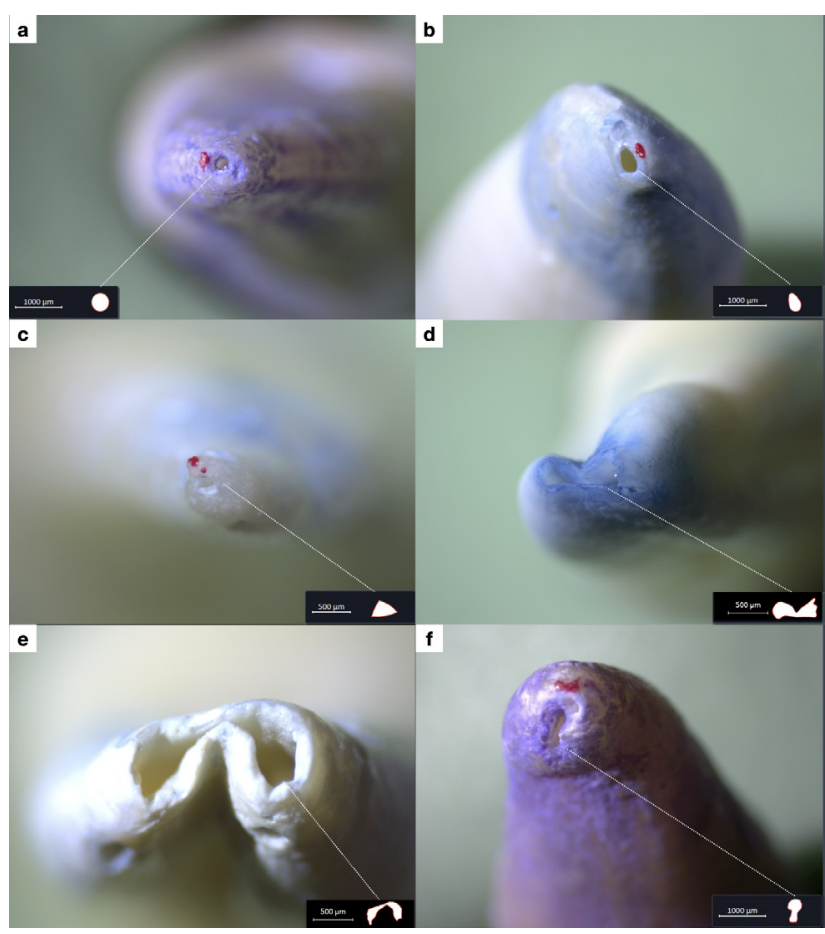

Fig. 4. Representative image data of different shapes of major AF. a; round-shape, b; oval-shape, c; triangleshape, $d$; ribbon-shape, e; C-type, f; irregular-shape. The dashed white line shows the duplicated illustration of the AF shape. AF: apical foramina.

The median (Q1-Q3) AF location with respect to the anatomic apex was $664 \mu \mathrm{m}(512-907 \mu \mathrm{m})$ in mandibular first premolars and $677 \mu \mathrm{m}(515-1053 \mu \mathrm{m})$ in mandibular second premolars Fig. $6(\mathrm{p}=0.371)$. There was no

significant correlation found between the size and location of the apical foramina for mandibular first premolar (rho $=0.035, \mathrm{p}=0.692)$ and second premolar teeth $($ rho $=-0.042, \mathrm{p}=0.651)$.

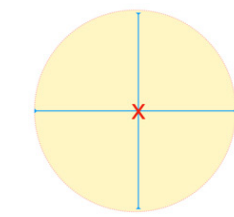

c

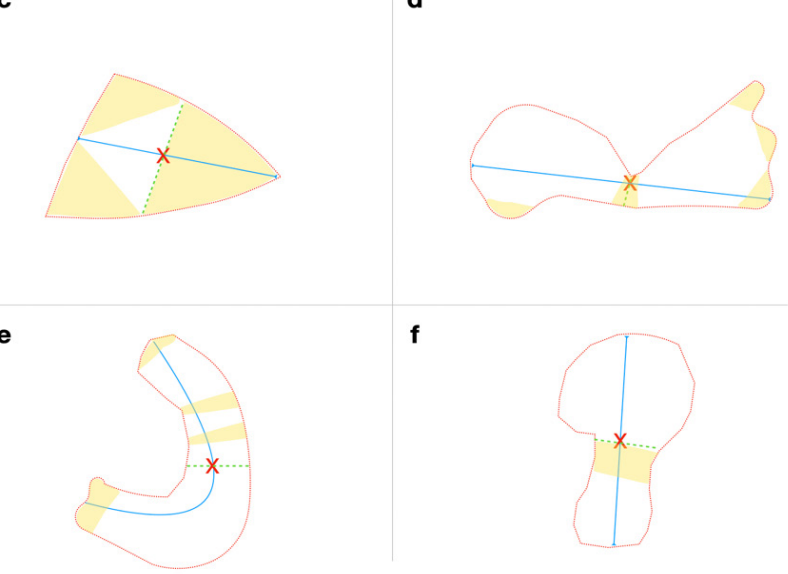

b

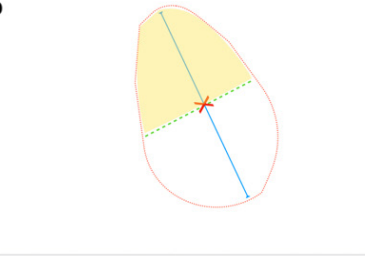

d
Fig. 5. The AF shapes are duplicated illustrations in Fig. 4. The "blue line" shows the measured widest distance across the ROI. The "dashed green line" shows the measured narrow distance of the ROI intersected at the center of the blue line. " $X$ " shows the center of the blue line. The "yellow region" shows the narrowest region of the ROI. $a$; round-shape, b; oval-shape, $c$; triangleshaped, $d$; ribbon-shape, $e$; C-type, $f$; irregularshape.AF: apical foramina, ROI: Region of interest of major apical foramina.

\section{DISCUSSION}

The present study investigated the apical morphology of mandibular first and second premolars of a young adult Turkish population. The size and location of apical foramina mostly overlap between the mandibular first and second premolars. Moreover, the shape of the apical foramina might be the only relevant variation concerning the apical morphology between the mandibular first and second premolars in young adults. In addition, the interaction between the size and location of apical foramina in mandibular premolars of young adults seem not significant. Regarding the Spearman's rho test, specimens with large AF size in mandibular first premolars had mostly long A-F distance (rho $=0.035$ ). In contrast, specimens with large AF size in mandibular second premolars had mostly short A-F distance $($ rho $=-0.042)$. 


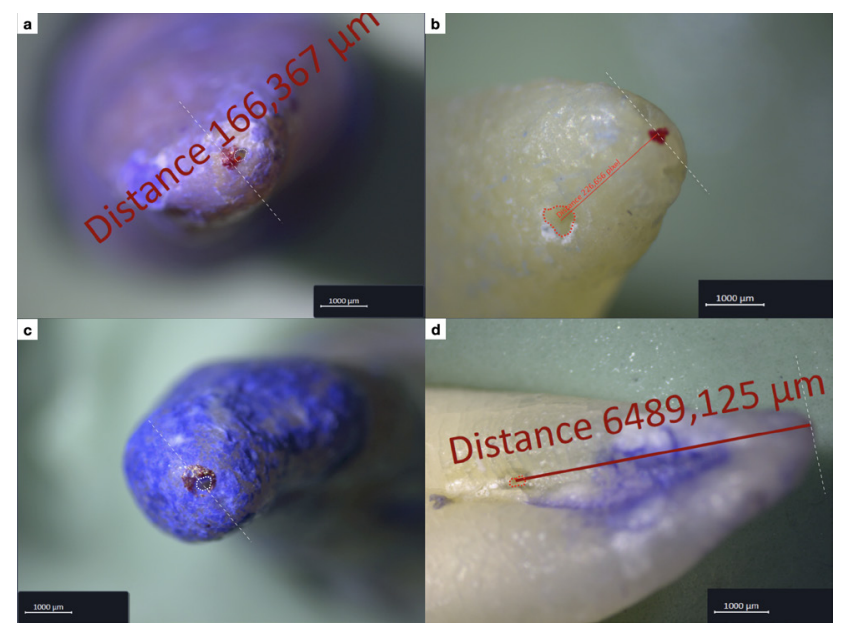

Fig. 6. Representative image data of the location of major apical foramina with respect to the anatomic apex. $a$; the intersection of major apical foramina and anatomic apex a specimen of the mandibular first premolars, $b$; the far location of major apical foramina from the anatomic apex in the mandibular first premolars, $c$; the intersection of major apical foramina and anatomic apex a specimen of the mandibular second premolars, $d$; the far location of major apical foramina from the anatomic apex in the mandibular second premolars. The white dashed line corresponds anatomic apex.

Recently, Awawdeh et al. (2019) have reported the apical morphology of 101 mandibular first premolars classified by age in a Jordan population. Of these, 31 (30.7\%) were between the ages of 19-35 (Awawdeh et al., 2019). The only information about the apical morphology in mandibular first premolars identified by age has been published in a recent report (Awawdeh et al., 2019). Our sample size consisted of 237 extracted teeth of young adults. Notably, this study provides apical morphological information about the mandibular premolars in a young adult Turkish population for the first time.

International organization for standardization no.3630 part 1 has been created for the root canal instruments (ISO 3630 part I, 2019). Accordingly, ISO\# 3630 part 1 covers the dimensions of root canal instruments adapted to root canal anatomy. Specifically, this international standard unconditionally assumes that the crosssectional shape of the root canal is "round". However, only $28.2 \%$ of the foramina were round-shaped in our specimens. Concordantly, the percentage of roundshaped apical foramina has been reported as $22.8 \%$ in a previous study (Awawdeh et al., 2019). The oval or irregular shape of the foramen represents a limitation of the current root canal instrumentation techniques.

Morphologically, apical foramina shape is clinically relevant. Since the shape of the apical foramina deductively reflects a cross-sectional view of the root canal anatomy, apical foramina with non-round shape is possibly a part of complicated root canal anatomy (Awawdeh et al., 2019). The majority of apical foramina shape has been reported as oval for mandibular premolars in previous studies (Marroquín et al., 2004; Arora and Tewari, 2009; Awawdeh et al., 2019). Similarly, the majority of specimens in mandibular second premolars had an oval shape. Also, oval AF was observed as the second common shape in the first premolars. Except for the oval or round shapes, different geometries such as triangular, kidney, or irregular have been also displayed for AF in the previous reports (Marroquín et al., 2004; Arora and Tewari, 2009; Awawdeh et al., 2019). In the present study, six different shapes were displayed for AF as round, oval, triangle, ribbon, C-type, and irregular. It can be seen that the frequency among shapes has differed compared to previous reports. These differences might be due to the racial characteristics of specimens.

Mandibular premolars of young adults in a Turkish population had mostly one apical foramen. Frequency of one major apical foramen for the first and second mandibular premolars was $110(89.4 \%)$ and $98(85.9 \%)$, respectively. Although the majority of the results were in agreement with the previous studies, the frequencies recorded in this study were higher than in previous reports (Awawdeh and Al-Qudah, 2008; Awawdeh et al., 2019). In a Jordanian population, one major AF has been reported as $64 \%$ for the mandibular first premolars (Awawdeh et al., 2019). Alike, the Awawdeh and AlQudah (2008) have shown the one major apical foramen as $58.2 \%$ and $72 \%$ for mandibular first and second premolars, respectively. The racial characteristics inferences could be made for the slight differences among the numbers.

A stereomicroscope and software were used for image data acquisition in this study. Previous reports have utilized similar universal study designs (Arora and Tewari, 2009; Awawdeh et al., 2019). To provide accurate data acquisition from each specimen, a precise integration from the lens to the software without any loss is important. Concordantly, the CZI image file format has been admitted as a bio-formatted file for dimensional analyses (https://docs.openmicroscopy.org/bio-formats/6.6.0/supported-formats.html). Hence, the authors emphasized that the materials used in the present study can be an advantage for the methodology.

The frequency of major AF was between 1-3 for both groups. The majority of the previous reports have shown that the count of major apical foramina is between 0-5 for mandibular premolars (Green, 1960; Awawdeh and Al-Qudah, 2008; Arora and Tewari, 2009; Awawdeh et al., 2019). A high frequency of AF 
has been correlated with the complex branching of the root canal at the apical region in a previous study (Biffi and Rodrigues, 1989). Orhan et al. (2017) have reported the negative correlation between the complex apical branching and the success of endodontic treatment in mandibular premolars. This might be attributed to the inefficient debridement of root canals related to the nonnegotiation of branching by orthograde instrumentation alone (Biffi and Rodrigues, 1989).

Previously, the size of AF has been expressed using the length of drawn two lines of maxima and minima (mm) across the canal openings (Awawdeh and AlQudah, 2008; Arora and Tewari, 2009; Awawdeh et al., 2019). Authors were suggested that the traces of canal curvatures inside the root can be misinterpreted as the minima distance of AF, therefore, the ROI was drawn tracing the major apical foramina in this study. Subsequently, the area of ROI was measured. Although these findings cannot be comparable with the previous studies due to unit conversion difficulties (Arora and Tewari, 2009; Awawdeh et al., 2019), comparisons could be made with the international standards as in Fig. 2 (ISO 3630 part I, 2019). Considering the median AF sizes in mandibular premolars, the final apical size should not be less than ISO size 45 in the young adult population. The discussion could be made by only the linear values of AF. In the present study, the median (min-max) wide and narrow diameters of AF in mandibular first premolars were $0.272 \mathrm{~mm}(0.051-0.786)$ and $0.194 \mathrm{~mm}(0.04-$ 0.441 ), respectively. Similarly, in a young adult (19-35year-old) Jordanian population, the mean wide and narrow diameters of AF have been reported as $0.280 \mathrm{~mm}$ (0.096-0.529) and $0.215 \mathrm{~mm}(0.084-0.369)$ in mandibular first premolars, respectively (Awawdeh et al., 2019). Also, the median wide and narrow diameters of AF in mandibular second premolars were $0.298 \mathrm{~mm}(0.11$ $0.863)$ and $0.213 \mathrm{~mm}(0.074-0.515)$, respectively, which were higher than the findings of Arora \& Tewari (2009). In the present study, the median maximum diameter of the AF ranged from 0.272 to $0.298 \mathrm{~mm}$ and the mean minimum diameter was in the range of 0.194$0.213 \mathrm{~mm}$. These values were in accordance with Arora and Tewari (2009) $(0.256-0.241 \mathrm{~mm} / 0.173-0.158)$ but lower than those reported by Green (1960) $(0.35-0.30$ $\mathrm{mm})$. The distinction between the average values in both premolars could be originated from age of the cohort and racial characteristics.

Determination of the working length with respect to the radiographic apex is not always a suitable method for allocating apical foramina. The variable characteristics of the location of the apical foramina should be con- sidered during the working length determination (Hassanien et al., 2008). In a North Indian (Haryana) population, the mean A-F distance has been reported for the mandibular first and the second premolars as $796 \mu \mathrm{m}$ and $781 \mu \mathrm{m}$, respectively (Arora and Tewari, 2009). In a Jordanian population, the mean A-F distance has been reported as $636 \mu \mathrm{m}$ (19-35-year-olds) and $650 \mu \mathrm{m}$ (3650 -year-olds) in the mandibular first premolars (Awawdeh et al., 2019). In the present study, the median A-F distance was between $664 \mu \mathrm{m}$ and $677 \mu \mathrm{m}$ in mandibular premolars. These findings show the complexity of the apical part in this Turkish population and the connection with reported populations of the world (Arora and Tewari, 2009; Awawdeh et al., 2019). In addition, these findings emphasize the importance of the electronic apex locators in mandibular premolars of young adults. Also, these findings of this study reinforced the justification of the current practice of apicoectomy at 3 $\mathrm{mm}$ level from the anatomic apex to provide the elimination of utmost of the non-negotiated canals (Kim and Kratchman, 2006).

Regarding analyzed image data, specimens were oriented until the apical foramina was positioned at the center of the primary lens to provide analysis of the accurate dimensions. Then two-dimensional image data were obtained from three-dimensional objects. Although digital bio-formatted image data sources are more suitable for morphologic target objects than counterparts, the dimensional reduction is might be a common limitation for stereomicroscopic investigations.

The major finding of the present study was the apical morphological characteristics of mandibular first premolars presented high similarity with the second premolars in the young adult population. The outcomes were mostly attributed to racial characteristics overall. However, these findings cannot represent the Turkish population in younger or older age groups than the selected age range. Considerably, the age of the patients can affect the apical foramina size (Awawdeh et al., 2019). Therefore, apical morphological impacts in different age ranges should be considered as another study in the future.

\section{CONCLUSIONS}

Shape, size, and location of major apical foramina are significant benchmarks to determine appropriate initial working length and width for the root canal treatment. The root canal anatomy of permanent mandibular premolars is highly variable. Within the limitations of this observational study, the following conclusions can be drawn: 
- The count, size and location of apical foramina mostly overlap between the mandibular first and second premolars of a young adult Turkish population.

- The shape of the apical foramina might be the only relevant variation concerning the apical morphology between the mandibular first and second premolars of a young adult Turkish population.

- There is no interaction between the apical foramina size and location in the mandibular first nor second premolars of a young adult Turkish population.

\section{ACKNOWLEDGMENTS}

Authors declare that this article is wholly from a thesis (Thesis owner: F. B., Instructor: E. O. O.., Thesis no: 10389022 available at Turkish Council of Higher Education). Research was supported by grants from the educational research project of Eskişehir Osmangazi University, Eskisehir, Turkey (201945A203). Mr. Tayfun Şengel, M.Sc. is gratefully acknowledged for his help with stereomicroscopic data collection. The authors declare no competing financial interests.

\section{Grant information}

Grant sponsor: Educational research project of Eskişehir Osmangazi University, Eskisehir, Turkey. Grant number: 201945A203

\section{Conflict of interests:}

None.

\section{REFERENCES}

Ahmed HMA, Versiani MA, De-Deus G, Dummer PMH (2017). A new system for classifying root and root canal morphology. Int Endod J 50:761-70. doi: 10.1111/iej.12685.

Arora S, Tewari S (2009). The morphology of the apical foramina in posterior teeth in a North Indian population. Int Endod J. 42:930-9. doi: 10.1111/j.13652591.2009.01597.x.

Awawdeh L, Abu Fadaleh M, Al-Qudah A (2019). Mandibular first premolar apical morphology: A stereomicroscopic study. Aust Endod J 45:233-40. doi:10.1111/aej.12313

Awawdeh LA, Al-Qudah AA (2008). Root form and canal morphology of mandibular premolars in a Jordanian population. Int Endod J 41:240-8. doi:10.1111/j.13652591.2007.01348.x

Biffi JC, Rodrigues HH (1989). Ultrasound in endodontics: a quantitative and histological assessment using human teeth. Endod Dent Traumatol 5:55-62. doi:10.1111/j.1600-9657.1989.tb00337.x

Blasković-Subat V, Maricić B, Sutalo J (1992). Asymmetry of the root canal foramina. Int Endod J 25:15864. doi:10.1111/j.1365-2591.1992.tb00779.x

Calişkan MK, Pehlivan Y, Sepetçioğlu F, Türkün M, Tuncer SS (1995). Root canal morphology of human permanent teeth in a Turkish population. J Endod 21:200-4. doi:10.1016/S0099-2399(06)80566-2

Dummer PM, McGinn JH, Rees DG (1984). The position and topography of the apical canal constriction and apical foramina. Int Endod J 17:192-8. doi:10.1111/j.1365-2591.1984.tb00404.x

European Society of Endodontology (2006). Quality guidelines for endodontic treatment: consensus report of the European Society of Endodontology. Int Endod J 39:921-30. doi:10.1111/j.1365-2591.2006.01180.x

Green D (1960). Stereomicroscopic study of 700 root apices of maxillary and mandibular posterior teeth. Or Surg Or Med Or Pa 13:728-33. doi:10.1016/00304220(60)90373-x

Gulabivala K, Aung TH, Alavi A, Ng YL (2001). Root and canal morphology of Burmese mandibular molars. Int Endod J 34:359-70. doi:10.1046/j.1365-2591.2001.00399.x

Hassanien EE, Hashem A, Chalfin H (2008). Histomorphometric study of the root apex of mandibular premolar teeth: an attempt to correlate working length measured with electronic and radiograph methods to various anatomic positions in the apical portion of the canal. $\mathrm{J}$ Endod 34:408-12. doi:10.1016/j.joen.2007.12.013

ISO 3630 (2019). Dentistry- Root-canal Instruments part 1: General requirements and test methods. Geneva: International Organization for Standardization ISO 3630 .

Kim E, Fallahrastegar A, Hur YY, Jung IY, Kim S, Lee SJ (2005). Difference in root canal length between Asians and Caucasians. Int Endod J 38:149-51. doi:10.1111/j.1365-2591.2004.00881.X

Kim S, Kratchman S (2006). Modern endodontic surgery concepts and practice: a review. J Endod 32:601-23. doi:10.1016/j.joen.2005.12.010

Lu TY, Yang SF, Pai SF (2006). Complicated root canal morphology of mandibular first premolar in a Chinese population using the cross section method. J Endod 32:932-6. doi:10.1016/j.joen.2006.04.008

Marroquín BB, El-Sayed MA, Willershausen-Zönnchen B (2004). Morphology of the physiological foramina: I. Maxillary and mandibular molars. J Endod 30:321-8. doi:10.1097/00004770-200405000-00005 
Open Microscopy Environment. URL: https://docs.openmicroscopy.org/bio-formats/6.6.0/supported-formats.html. [accessed: 12 April 2021].

Orhan EO, Dereci Ö, Irmak Ö (2017). Endodontic Outcomes in Mandibular Second Premolars with Complex Apical Branching. J Endod 43:46-51. doi:10.1016/j.joen.2016.09.006

Peiris R (2008). Root and canal morphology of human permanent teeth in a Sri Lankan and Japanese population. Anthropol Sci 116: 123-33. doi:10.1537/ase.070723

Ricucci D (1998). Apical limit of root canal instrumentation and obturation, part 1. Literature review. Int Endod J 31:384-93. doi:10.1046/j.1365-2591.1998.00184.x

Sert S, Bayirli GS (2004). Evaluation of the root canal configurations of the mandibular and maxillary permanent teeth by gender in the Turkish population. J Endod 30:391-8. doi:10.1097/00004770-200406000-00004

Song JS, Choi HJ, Jung IY, Jung HS, Kim SO (2010). The prevalence and morphologic classification of distolingual roots in the mandibular molars in a Korean population. J Endod 36:653-7. doi:10.1016/j.joen.2009.10.007

Stein TJ, Corcoran JF (1992). Radiographic "working length" revisited. Or Surg Or Med Or Pa 74:796-800. doi:10.1016/0030-4220(92)90412-j
Trope M, Elfenbein L, Tronstad L (1986). Mandibular premolars with more than one root canal in different race groups. J Endod 12:343-5. doi:10.1016/S00992399(86)80035-8

Vertucci FJ (1978). Root canal morphology of mandibular premolars. J Am Dent Assoc 97:47-50. doi:10.14219/jada.archive.1978.0443

Vertucci FJ (2005). Root canal morphology and its relationship to endodontic procedures. Endod Topics 10:3-29. doi:10.1111/j.1601-1546.2005.00129.x

Walker RT (1988). Root canal anatomy of mandibular first premolars in a southern Chinese population. Endod Dent Traumatol 4:226-8. doi:10.1111/j.1600-9657.1988.tb00326.x

Wu MK, Wesselink PR, Walton RE (2000). Apical terminus location of root canal treatment procedures. Oral Surg Oral Med O 89:99-103. doi:10.1016/s10792104(00)80023-2

Zhang Q, Chen H, Fan B, Fan W, Gutmann JL (2014). Root and root canal morphology in maxillary second molar with fused root from a native Chinese population. J Endod 40:871-5. doi:10.1016/j.joen.2013.10.035

Zillich R, Dowson J (1973). Root canal morphology of mandibular first and second premolars. Or Surg Or Med Or Pa 1973;36:738-44. doi:10.1016/0030-4220(73)90147-3. 